Eduvest - Journal of Universal Studies

Volume 2 Number 1, January 2022

p- ISSN 2775-3735 e-ISSN 2775-3727

\title{
TOURISM DEVELOPMENT STRATEGY BASED ON LOCAL WISDOM IN IMPROVING THE WELFARE OF LOCAL COMMUNITIES
}

\author{
Herly Methelda Oematan, Maria Elerina Douk Tunti, Siprianus G. Tefa \\ 1,2,3 Nusa Cendana University, Indonesia \\ E-mail: gherly_rohi@yahoo.com,maria.tunti@staf.undana.ac.id, \\ sipri.tefa999@gmail.com
}

\begin{tabular}{|c|c|}
\hline ARTICLE INFO & ABSTRACT \\
\hline 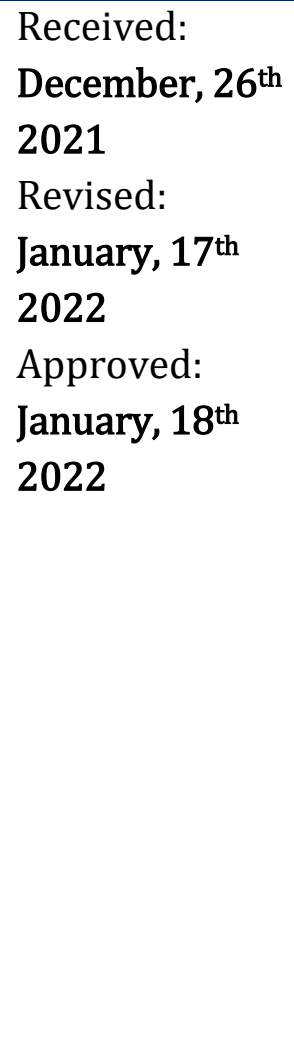 & $\begin{array}{l}\text { This study aims to formulate a tourism development } \\
\text { strategy based on local wisdom in improving the welfare } \\
\text { of local communities in the Districts of North Mollo, } \\
\text { Central Mollo, South Mollo, and Fatumnasi, South Central } \\
\text { Timor Regency, NTT Province. This research is a } \\
\text { quantitative descriptive study using questionnaires, } \\
\text { observation and documentation as data collection } \\
\text { methods. The analytical tool is a SWOT analysis in order to } \\
\text { find out internal and external factors that will be } \\
\text { strengths and weaknesses as well as opportunities and } \\
\text { threats in the development of tourism based on local } \\
\text { wisdom. Research respondents consisted of visitors to } \\
\text { tourism sites, village officials and local residents in the } \\
\text { tourist areas of North Mollo, Central Mollo, South Mollo, } \\
\text { and Fatumnasi. The results show that the sub-districts of } \\
\text { North Mollo, Central Mollo, South Mollo, and Fatumnasi } \\
\text { have internal and external tourism potential, namely local } \\
\text { wisdom in the form of beautiful nature and fresh air as } \\
\text { well as serving local agricultural products and local home } \\
\text { industry products which are processed professionally } \\
\text { through MSMEs. -MSMEs that have local characteristics }\end{array}$ \\
\hline
\end{tabular}

Herly Methelda Oematan, Maria Elerina Douk Tunti, Siprianus G.

Tefa (2022). Implementation Analysis of Isak 35 In Financial

Reporting of The GMIT Church in Indonesia. Journal Eduvest.

2(1): $1-13$

How to cite:

E-ISSN:

Published by: https://greenpublisher.id/ 


\begin{tabular}{ll}
\hline & $\begin{array}{l}\text { that cannot be obtained by visitors in other areas. This is a } \\
\text { differentiating factor with other tourist sites in NTT. }\end{array}$ \\
\hline KEYWORDS & Tourism, Local Wisdom, Welfare improvement, SWOT \\
\hline cc) (1) (9) & $\begin{array}{l}\text { This work is licensed under a Creative Commons } \\
\text { Attribution-ShareAlike 4.0 International }\end{array}$ \\
\hline
\end{tabular}

\section{INTRODUCTION}

The tourism sector has an increasingly important role for the Indonesian economy at the macro level. In 2018 foreign tourists were recorded at 15.81 million people with a growth rate of $12.58 \%$ (BPS, 2019) and foreign exchange contributions of USD 16.1 billion (Kemenpar, 2019). In the same year, domestic tourists recorded 303.4 million trips with a growth of $12.37 \%$ (BPS, 2019) with a total expenditure of IDR 291 trillion and a growth rate of $17.9 \%$ (Kemenpar, 2019). Thus it can be said that tourism somehow has a role and makes a major contribution in improving the welfare of the people where tourism objects are developed (Yoeti, 2008). This achievement is in line with the mandate of Law Number 10 of 2009 concerning Tourism which states that the implementation of tourism is aimed at increasing national income in order to improve the welfare and prosperity of the people, expand and equalize business opportunities and employment opportunities, encourage regional development, introduce and utilize objects and tourist attraction in Indonesia and foster a sense of love for the homeland and strengthen friendship between nations and most importantly in accordance with the national research master plan for 2017-2045, namely preserving local wisdom from local communities for tourism development in the future.

The Provincial Government of East Nusa Tenggara (NTT) under the leadership of Governor Viktor Laiskodat focuses on 5 (five) main programs, namely 1) tourism, 2) people's welfare, 3) human resources, 4) infrastructure, and 5) bureaucratic reform. The University of Nusa Cendana Kupang is also in the strategic plan for 2017-2021 as a partner of the government and also focuses on developing the tourism economy with the aim of improving people's welfare. In order to realize the welfare of the people in NTT, one of the missions of the NTT Regional Government as outlined in the 2018-2023 RPJMD is the development of the tourism economy by encouraging economic actors to be able to take advantage of local potential. This is because tourism has three aspects of influence, namely economic aspects (sources of foreign exchange and taxes), social aspects (job creation) and cultural aspects (Hartono in Hanny Aryunda, 2011). The existence of the tourism sector should receive support from all parties such as local governments as managers, communities in tourism objects, private sector participation as developers and universities as government partners who contribute constructive thinking in tourism development.

NTT is one of the provinces that has abundant natural resource potential. Geographical conditions and characteristics of the unspoiled territory and the culture of the people who are still oriented to local wisdom make NTT has various potential tourist attractions which, if successfully developed, will improve the welfare of the community and become a source of income for the region and the state. South Central Timor Regency (TTS) which has very beautiful natural tourism potential. As one of the development sectors that can spur economic growth and community welfare, tourism is considered a strategic asset to encourage development and economic growth in the TTS Regency area. 
Some of the advantages of TTS are: 1) Located at an altitude of 800-1000 meters above sea level so as to make the air cool, 2) Has a variety of potential and tourist attractions in the form of mountains, beaches and cultural tourist attractions, 3) Its strategic location, is in a middle position between the regencies on the mainland of Timor, which is a transit area that connects the capital city of NTT Province (Kupang City) with two other district capitals, namely the Regencies of North Central Timor (TTU) and Belu to the neighboring Democratic State of Timor Leste. which is a gateway for foreign tourists (TTS Regency Culture and Tourism Office, 2014 in Mellu, et al, 2018).

Table 1 Number of International and Domestic Tourists in NTT 2017-2019

\begin{tabular}{llll}
\hline Year & \multicolumn{2}{c}{ Tourist } & Total \\
\cline { 2 - 3 } & Overseas & Domestic & \\
\hline 2017 & 93.455 & 523.083 & 616.538 \\
\hline 2018 & 123.686 & 682.777 & 806.463 \\
\hline 2019 & 112.806 & 456.461 & 569.267 \\
\hline
\end{tabular}

Source: NTT in Figures, 2019

Viewed from Table 1, it can be said that the level of tourist visits in NTT has fluctuated. However, at the beginning of 2020 the world was hit by the COVID-19 pandemic. This had an impact on the world tourism sector, including in NTT. In May 2020, the number of tourists to NTT did not reach 30,000 people (economy.bisnis.com).

Despite experiencing a decline in PAD from the tourism sector, the regional government of TTS remains optimistic in increasing revenue from the tourism sector after the implementation of the new normal, especially since all types of tourism in TTS are natural tourism that meets the criteria for the Health protocol. The government will continue to try to maintain tourism conditions because this sector is considered to be a sector capable of accelerating economic growth in order to reduce poverty in the TTS district. According to the Regent of TTS, during the Deliberation on the Development Plan (Musrembang) of the 2019 Regional Development Work Plan (RKPD), many tourism objects in TTS have not been managed optimally as tourist destinations. So the problem faced is the low management of tourist destinations which has an impact on the low PAD of TTS. According to him, if existing tourism objects are managed optimally to become income for the region, it will have an impact on the economic growth of the community because other sectors such as small and medium enterprises in the community are also active (http://ttskab.go.id, March 26, 2019).

In accordance with the strategy and direction of the TTS district development policy for 2019-2024, it is contained in the 4th mission, namely "Increasing people's income (Tourism, Agriculture, animal husbandry, fisheries, industry, trade, cooperatives, MSMEs, and BUMDES)". In this 4th mission, the tourism sector becomes a leading sector with strategies made, namely: 1) increasing the number of tourist destinations, 2) increasing the number of tourists, and 3) increasing the accessibility of tourist destinations, increasing the economy for local communities around tourism objects (Regency RPJMD). TTS 2019-2024).

Departing from the strategy and policy direction of the 2019-2024 TTS district development, the vision of the TTS Tourism Office, namely the TTS tourism object, must be a leading destination in the NTT Province. This vision will be pursued by carrying out four missions, namely 1) developing tourism potential, 2) developing promotion and marketing, 3) developing the tourism industry, and 4) developing human resources (http://ttskab.go.id, 11 April 2018) . 
There are several things that have not been managed and developed properly based on strategic issues of cultural and tourism development in the TTS district in terms of the description of SKPD services, the medium-term targets in the NTT Strategic Plan and the 2014-2019 TTS District Spatial Plan (RTRW): (1) not yet known all the potential objects and tourist attractions, both cultural, natural and special interests, (2) not all areas of the TTS district have been traversed with adequate access, (3) tourism institutions have not been organized, including coordinating institutions related to policy making, tourism actors, including promotion agencies, (4) tourism promotion and tourism marketing are still being carried out separately, which should be formed by a cooperative body to promote cultural tourism attractions, tourism packages, and so on, (5) the limited amount of investment in tourism can show the role of the private sector and the community is not optimal, (6) the competitiveness of tourism destinations national tourism, among others, inadequate facilities and infrastructure and less than optimal management of destinations, (7) public awareness in the tourism object environment in capturing business opportunities/creative economy is very lacking, (8) limited budget platform in the tourism sector (Renstra of TTS Regency Tourism Office 2015-2019 in Mellu, et al, 2018). This is the reason why so many tourist attractions are not well developed especially new tourist attractions. The various obstacles above are also faced by various tourist objects scattered in the sub-districts of North Mollo, Central Mollo, South Mollo and Fatumnasi, TTS Regency.

Local wisdom is a strategy used in attracting tourists to visit a destination or tourist attraction. This research is expected to be able to provide data and information related to the potential and recommendations for tourism development strategies that have local wisdom in the Mollo and Fatumnasi regions. The tourism sector requires a strategy with a planned or structured pattern of tourism development so that its potential can be developed optimally (Primadany 2013). With this in mind, this study aims to formulate a tourism development strategy based on local wisdom in improving the welfare of local communities in the Mollo and Fatumnasi areas, TTS NTT Regency.

\section{RESEARCH METHOD}

This study uses a descriptive approach. The population of this research is users of tourist objects (tourists) who use tourism objects in the sub-districts of North Mollo, Central Mollo, South Mollo and Fatumnasi, TTS as well as communities located around tourist objects, as well as the local government of TTS. The sampling method used accidental sampling technique consisting of tourists and residents around the tourist attraction. Specifically for the TTS Regional Government, the sampling technique uses purposive sampling where the samples are taken using the criteria of tourism policy makers in this case the head of the TTS Regency Tourism Office, the head of the section (kabag) and the head of the subsection (kasubag) at the TTS Tourism Office. The total sample to be used is 250 samples.

\section{Research Flow Stages}

This research includes the stages of inventory, analysis and evaluation, and the concept of tourism development.

1. Inventory Stage

Inventory is the collection of primary and secondary data from a location at this time. Primary and secondary data consist of physical, biophysical, and social aspects. Data is obtained in the following ways: a. Field observations were carried out to determine site conditions, including physical conditions, biophysical conditions, landscape characters, and activities of the user community and its surroundings; 2) 
Interviews conducted with visitors, communities, and managers;

2. Data Analysis

To map and process research results using the Variables, Dimensions, and Indicators of each Variable to determine tourism development strategies for the Mollo and Fatumnasi regions, TTS uses SWOT analysis techniques to maximize strengths and opportunities, and minimize weaknesses. (weakness) and threats (treat). Then determine the internal environment (IFAS) to find out various possible strengths and weaknesses and analyze the external environment (EFAS) to find out various possible opportunities and threats.

3. Tourism Object Development Strategy

The action is determined by the IFE and EFE Matrix. Quadrants I, II, and IV are perceived as grow and build actions. An intensive and integrative strategy can be used as an appropriate approach. Alternative preparation is done by combining internal factors with external factors. The combinations include SO (strengths and opportunities), ST (strengths and threats), WO (weaknesses and opportunities) and WT (weaknesses and threats). Determining the priority of alternative strategies is done by adding up all the scores of the constituent factors. The strategy that has the highest score is the top priority.

\section{Research sites}

This research was conducted in the Districts of North Mollo, Central Mollo, South Mollo and Fatumnasi, TTS District, NTT.

\section{Data Types and Sources}

a) Primary data was obtained through distributing questionnaires, direct observation to tourist sites in the Mollo and Fatumnasi areas, TTS. Primary data was conducted through a questionnaire to determine public perceptions about the condition of tourist objects in the Mollo and Fatumnasi areas, TTS. Direct observations and interviews with parties related to the location of tourist objects were carried out to identify the characteristics of tourism objects, obstacles and tourism potential in the Mollo and Fatumnasi regions, TTS.

b) Secondary data obtained through various documents containing information supporting the research.

\section{Analysis Tools}

The analytical tool used is a SWOT analysis.

\section{RESULT AND DISCUSSION}

\section{SWOT Analysis Results}

\section{1) Internal Factor Analysis}

Internal factors are entered into a matrix called the internal strategy factor matrix or IFAS (Internal Factor Analysis Summary).

Table 2 IFAS . Weights, Ratings and Scores

$\begin{array}{llll}\text { INTERNAL STRATEGIC FACTORS } & \text { Weight } & \text { Rating } & \begin{array}{l}\text { Score = } \\ \text { Weight } \\ \text { Strenght }\end{array} \\ \begin{array}{llll}\mathbf{R} \text { Rating } \\ \text { 1. Pleasant natural scenery and clean air quality }\end{array} & 7,18 & 0,17 & 1,19 \\ \text { 2. Strategic tourist location } & 6.79 & 0,15 & 1,05 \\ \text { 3. Easy access to tourist sites } & 5,66 & 0,14 & 0,77 \\ \text { 4. Availability of public facilities and } 5,00 & 0,12 & 0,60\end{array}$
infrastructure, namely public toilets, trash cans, security guards and health protocol facilities (during the Covid 19 pandemic) 
5. Receive budget support from the TTS 5,27

$0,12 \quad 0,66$

Regency Government and the Village

Government as well as moral support from

local village community leaders

6. Government protected area

7. Local people who are friendly to visitors

Total Strenght

Weakness

$$
\text { (1) }
$$

6,08
, 78

$\begin{array}{ll}0,14 & 0,84 \\ 0,16 & 1,08 \\ \mathbf{6 , 2 0} & \end{array}$

Weight Rating $\quad$ Score $=$ Weight

1. Tourism promotion media that is still lacking

2. There is no sponsorship from a third party for the existing tourist sites

3. Tourists visit only at certain times

4. The lack of an entrepreneurial spirit from the community around tourist sites
5. There are no arts and cultural attractions that are synchronized with the tourist agenda

\section{Total Weakness}

Source of data: Primary, processed by researchers, 2021

x Rating

$-1,39$

$-6,19 \quad 0,20 \quad-1,23$

$-5,87 \quad 0,20 \quad-1,16$

$-6,02 \quad 0,20 \quad-1,19$

$-6,12 \quad 0,20 \quad-1,19$

From Table 3 above, it can be explained that the highest strength value is in the items of pleasant tourist natural scenery and clean air quality with a score of 1.19 and a weight of 7.18 while the biggest weakness is in tourism promotion media items which are still lacking with a score of 1.19. -1.39 and a weight of -6.53 . This shows that the beautiful nature and fresh air in the Mollo and Fatumnasi sub-districts are their own strengths or differentiating factors from other tourist sites in attracting tourists, although for now these locations have not been promoted regularly by the government or other stakeholders.

\section{External Factor Analysis}

External factors are entered into a matrix called the EFAS external strategy factor matrix (External Factor Analysis Summary).

Table 4 EFAS . Weights, Ratings and Scores
EXTERNAL STRATEGIC FACTORS
Opportunities
$\begin{aligned} & \text { Weight } \\ & \text { 1. Improving the economy of the }\end{aligned}$ 年,
$\begin{aligned} & \text { community where the tourist location is } \\ & \text { located }\end{aligned}$


7. Many institutions/third parties have $2,32 \quad 0,12 \quad 0,27$ concerns and can be used as partners in tourism development

8. Availability of budget from the TTS District Government to facilitate training related to tourism and life skills to the community

\section{Total Opportunities}

$2,12 \quad 0,11 \quad 0,23$

\section{Threat}

Weight

1. Tourist sites that are prone to natural disasters such as fires and landslides

2. Visitors' indiscipline in preserving the nature of tourism, such as littering

3. Land ownership disputes between residents of tourist sites

4. The act of intentionally destroying tourist sites by local residents

\section{Total Threat}

Source of data: Primary, processed by researchers, 2021

From Table 4 above, it can be explained that the highest opportunity value is in the momentum for the promotion of local community agricultural products with a score of 0.39 and a weight of 2.79. Meanwhile, the biggest threat is the visitor's indiscipline item in preserving the nature of tourism, such as littering with a score of -0.80 and a weight of -2.48 . This means that when tourist visitors visit tourist locations in the Mollo and Fatumnasi sub-districts, the opportunity is used by the community around tourist sites to promote agricultural products, home industry products and even these products are also sold to visitors. tour. On the other hand, the presence of tourist visitors also creates its own problems for tourist sites where many visitors are not disciplined in disposing of waste in existing tourist sites.

Judging from the results of the IFAS table analysis above, it shows that the strength factor obtained a total score of 6.20 and the weakness factor obtained a total score of -6.15 with a difference in score of $(+) 0.05$. This means that the strength factor is greater than the weakness factor. While the EFAS table shows that the opportunity factor gets a score of 2.51 and the threat factor gets a total score of -.2 .13 with a difference in score of (+) 0.38. This means that tourism-related opportunities in the Mollo and Fatumnasi sub-districts can be maximized to reduce existing threats. Graphically, the results of the identification of internal and external factors can be explained in the image and SWOT diagram below: 


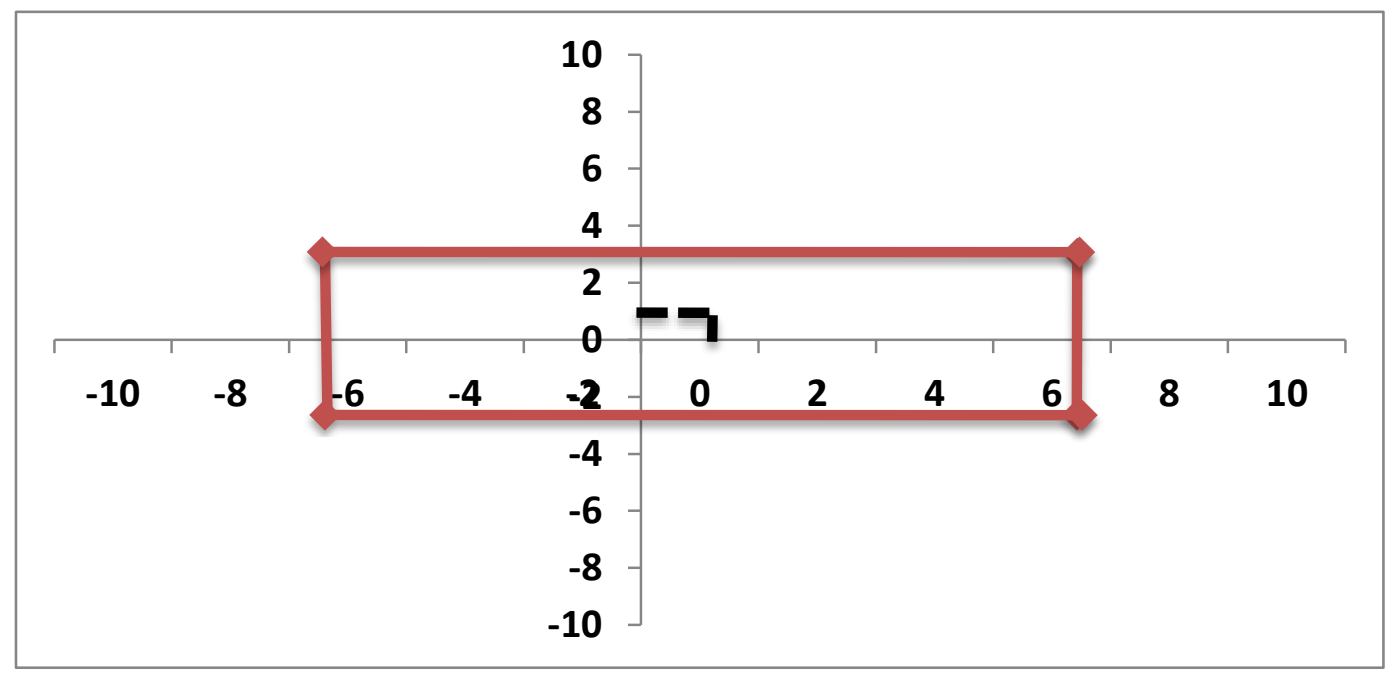

Figure 2 SWOT Chart

Source: Primer, processed by researchers, 2021

\section{Disscussion}

In order to find out the tourism management strategy in the Mollo and Fatumnasi sub-districts, a SWOT matrix is needed that can show the strengths, weaknesses, opportunities and threats that exist in the Mollo and Fatumnasi sub-districts. Based on the SWOT matrix, it can clearly describe the results of the SWOT analysis related to tourism management strategies in the Mollo and Fatumnasi sub-districts as follows:

Tabel 5 Matriks SWOT Pengelolaan Pariwisata di wilayah Kecamatan Mollo dan

Fatumnasi

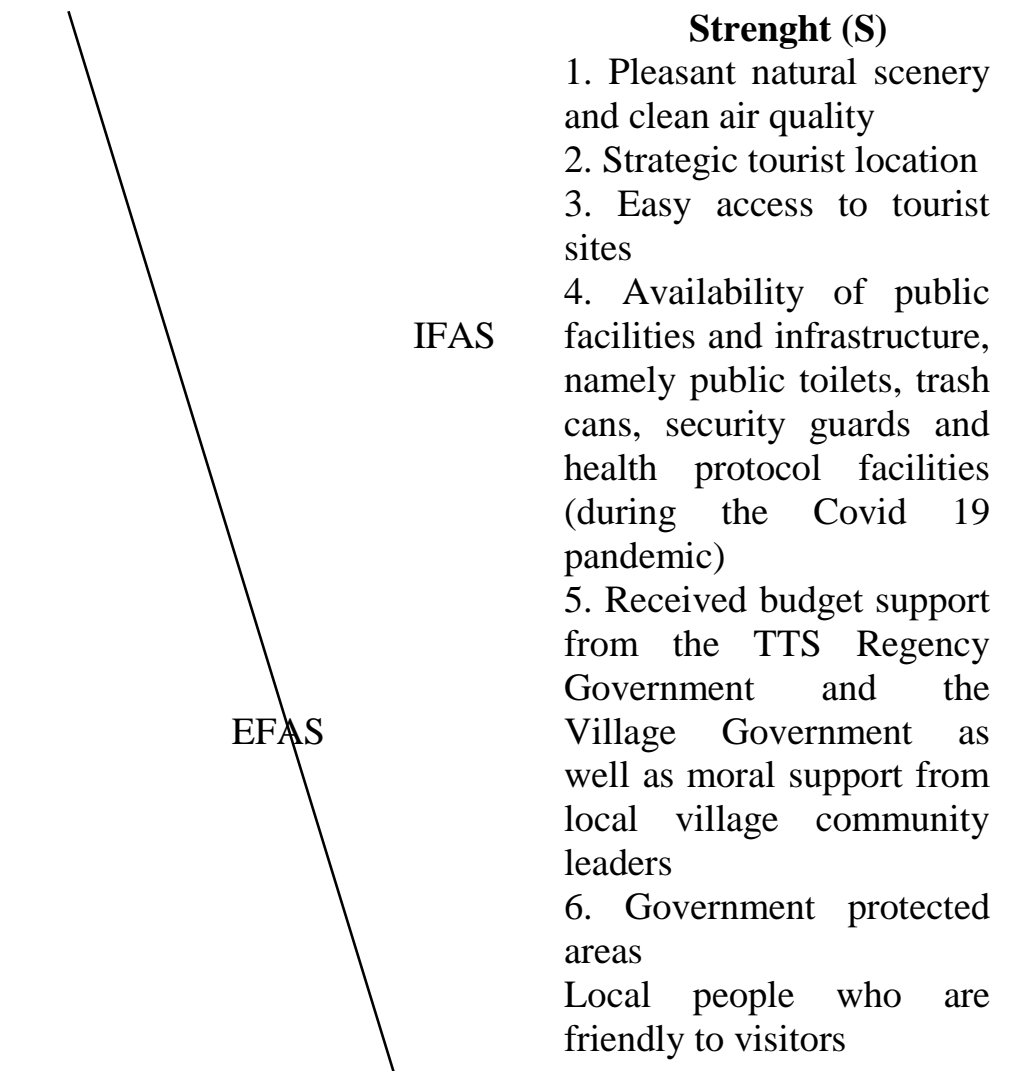

\section{Weakness (W)}

1. Tourism promotion media is still lacking 2. There is no sponsorship from a third party for the existing tourist sites

3. Tourist visitors visit only at certain times

4. The lack of entrepreneurial spirit from the community around the location 5. There are no arts and cultural attractions that are synchronized with the tourist agenda 


\section{Oppurtunities (O)}

1. Improving the economy of the community where the tourist location is located

2. The creation of new job opportunities for the local community

3. Increasing Village PAD

4. Momentum for local arts and cultural attractions

5. Momentum for promotion of local community agricultural products

6. Many media including social media are available for tourism promotion

7. Many institutions/third parties have concerns and can be used as partners in tourism development

Availability of budget from the TTS Regency Government to facilitate training related to tourism and life skills to the community.

\section{SO Strategy}

1. Pleasant tourist natural scenery and clean air quality, strategic tourist locations, easy access to tourist sites are the determining factors for high tourist visits. This momentum must be used by residents around tourist sites to not only promote their agricultural products but can sell them to visitors which can improve the local community's economy. On the other hand, there are currently many media, including social media, that can be used not only to promote existing tourist sites but also to promote agricultural products from communities around tourist sites. The strategy that can be formulated in this regard is the preparation of an expert and skilled workforce in mastering technology and information that focuses on promoting tourism potential and the economic potential of the community around tourist sites by using various platforms such as websites and social media such as YouTube, Facebook, Instagram and so.

\section{WO Strategy}

Tourist visitors only visit at certain times, there is a lack of entrepreneurial spirit from the community around the location and there are no artistic and cultural attractions that are synchronized with the tourist agenda. In fact, if there is an effort to increase tourist visitors, it will have an economic impact on residents as well as an increase in PADDes for villages in tourist locations. For this reason, the strategy that can be formulated is that the Village Government initiates and explores cooperation with third parties who can provide tourism management training, entrepreneurship

training/soft skills entrepreneurship and involve event organizers in managing and increasing the potential of artistic and cultural attractions in the villages. tourist location village. 
2. Budget support from the
TTS Regency
Government and the
local Village
Government will
facilitate and expedite
the economic activities
of the community
around the tourist sites
so that the strategy that
can be formulated is the
preparation of a budget
using a budget
participation model both at the APBD II and APBDes levels so that the budget needs of the community around the location Tourism can be accommodated by the TTS Regency Government and the Village Government.

Treath (T)

1. Tourist locations that are prone to natural disasters such as fires and landslides

2. Visitors' indiscipline in preserving the nature of tourism, such as throwing garbage carelessly

3. Land ownership disputes between residents of tourist sites

4. The act of intentionally destroying tourist sites by local residents

\section{ST Strategy}

Visitors are undisciplined in preserving the existing tourism nature even though the existing tourist areas are areas protected by the government, both by the local village government and the TTS district government so that the strategy that can be formulated is making regulations by the village government through the tourism village regulation and the TTS district government through local regulations and socialization and supervision of the implementation of these regulations to all tourism stakeholders including tourist visitors.
WT Strategy

There is no sponsorship from a third party for existing tourist sites and there are no artistic and cultural attractions that are synchronized with the tourism agenda so that the strategy that can be formulated is that the Village Government and TTS Regency Government work together to explore opportunities for collaboration with other parties/institutions that are mutually beneficial to each other. . In addition, both the Village Government and the TTS Regency 
Source: Primer, processed by researchers, 2021.

\author{
Government through \\ the Tourism Office can \\ synchronize \\ government agendas \\ with the agendas of \\ artistic and cultural \\ attractions at the tourist \\ sites of each village.
}

\section{CONCLUSION}

Based on the results of the SWOT analysis in this study, it can be concluded several things as follows:

1) From table 6.1 it can be explained that the highest strength value is in the items of pleasant tourist natural scenery and clean air quality with a score of 1.19 and a weight of 7.18 while the biggest weakness is in tourism promotion media items which are still lacking with score -1.39 and weight -6.53 . This shows that the beautiful nature and fresh air in the Mollo and Fatumnasi sub-districts are their own strengths or differentiating factors from other tourist sites in attracting tourists, although for now these locations have not been promoted regularly by the government or other stakeholders.

2) From Table 6.2 above, it can be explained that the highest opportunity value is in the momentum for the promotion of local community agricultural products with a score of 0.39 and a weight of 2.79. Meanwhile, the biggest threat is the visitor's indiscipline item in preserving the nature of tourism, such as littering with a score of -0.80 and a weight of -2.48 . This means that when tourist visitors visit tourist locations in the Mollo and Fatumnasi sub-districts, the opportunity is used by the community around tourist sites to promote agricultural products, home industry products and even these products are also sold to visitors. tour. On the other hand, the presence of tourist visitors also creates its own problems for tourist sites where many visitors are not disciplined in disposing of waste in existing tourist sites.

3) Judging from the results of the IFAS table analysis above, it shows that the strength factor obtained a total score of 6.20 and the weakness factor obtained a total score of -6.15 with a difference in score of $(+) 0.05$. This means that the strength factor is greater than the weakness factor. While the EFAS table shows that the opportunity factor gets a score of 2.51 and the threat factor gets a total score of - .2 .13 with a difference in score of (+) 0.38 . This means that tourismrelated opportunities in the Mollo and Fatumnasi sub-districts can be maximized to reduce existing threats.

\section{REFERENCES}

Anwar, dkk, 2018; Strategi Pengembangan Wisata Bebrasis Kearifan Lokal di Kalimantan Selatan, Jurnal Kebijakan Pembangunan, Vol 13, No.2 , Desember 2018 
Aryunda, Hanny, 2011; Dampak Ekonomi Pengembangan Kawasan Ekowisata Kepulauan Seribu, Jurnal Perencanaan Wilayah dan Kota, Volume 22, Nomor 1, April, hal. 1-16. 2.

Cooper, John Fketcher, David Gilbert and Stephen Wanhill, 1995; Tourism, Principles and Prantice. London. Logman.

Divisekera and Kulendran, 2006; Economic Effects of Advertising on Tourism

Demand: A Case Study, Tourism Economics, Juni 2006, 12 (2), 187-205.

Ismayanti, 2010; Pengantar Pariwisata, PT. Grasindo, Jakarta.

Kabu, Melky, 2019; Pengaruh Daya Tarik Wisata dan Aksesibilitas Terhadap Tingkat Kunjungan Wisata ke Desa Boti Kabupaten Timor Tengah Selatan, Journal Tourism, Vol.2, No.01, Hal.24-31.

Lickorish, Leonard J, et al, 1994, Developing Tourism Destination : Policies and Perspective, Longman Group, UK.

Marpaung, Fernando, 2009; Strategi Pengembangan Kawasan Sebagai Sebuah

Tujuan Wisata, Tesis PS, Magister Kajian Pariwisata, UGM, Yogyakarta.

Mellu, dkk,2018; Analisis Faktor Penunjang dan Penghambat Pengembangan

Objek Wisata (Studi pada Objek Wisata Alam Bola Palelo, Kecamatan

Mollo Tengah, Kabupaten Timor Tengah Selatan), JOURNAL OF

MANAGEMENT (SME's) Vol. 7, No.2, 2018, p269-286.

Mill, Robert Christie, 2000; Tourism, The International Business: Terjemahan Tri

Budi Satrio. Jakarta: Penerbit Raja Grafindo.

Muljadi dan Warman, 2014; Kepariwisataan dan Perjalanan, Jurnal Ilmu Indonesia, Jakarta.

Pemerintah Republik Indonesia. Undang-Undang No.10 Tahun 2009 tentang Kepariwisataan .

Sanam, Syul Rosli, 2019; Strategi Pengembangan Air Terjun Oehala Sebagai Daya Tarik Ekowisata Berbasis Masyarakat di Kabupaten Tengah Selatan, Nusa Tenggara Timur, JUPAR-Jurnal Pariwisata, Vol.2, No.02, Hal.7282 .

Samuelson, Paul A. 2001. Makro-Ekonomi Edisi Ke-14, Penerbit Erlangga, Jakarta.

Suryadana M. Liga \& Octavia, Vanny, 2015; Pengantar Pemasaran Pariwisata, Penerbit Alfabeta, Bandung.

Stynes, Daniel, J. 1999; "Economic Impacts of Tourism". Di akses tanggal 10 Agustus 2019 melalui ttps://www.msu.edu/course/prr/840/econimpact/pdf/ecimpvol1.pdf

Sugiarto, 2007; Teori Kesejahteraan Sosial Ekonomi dan Pengukurannya, Jurnal Eksekutif, Agustus, Vo.4, No.2.

Su'ud, 1991; Alokasi Sumber Daya dan Pola Usaha Tani Dalam Hubungan dan Kondisi Sosial Ekonomi Petani, kasus Antar Zona Pembangunan di Provinsi Daerah Istimewah Aceh. Universitas Syiah Kuala Darusalam Banda Aceh.

Tapatfeto, Bessie, dan Kasim, 2018; Strategi Pengembangan Objek Wisata Dalam Upaya Peningkatan Kunjungan (Studi pada Objek Wisata Pantai Oetune 
Kabupaten TTS), JOURNAL OF MANAGEMENT (SME's) Vol. 6, No.1, 2018, p1-20.

Tjiptono, Fandi, 1995; Strategi Pemasaran, Penerbit Andi Offset, Yogyakarta.

Todaro MP, Stephen C Smith, 2003; Pembangunan Ekonomi di Dunia Ketiga Jilid I Edisi ke8, Penerbit Erlangga, Jakarta.

Wahab, 1992; Manajemen Kepariwisataan. Penerjemah Frans Gromang. Jakarta : Pradnya Paramita

Yoeti, O.A, 2008; Pengantar Ilmu Pariwisata. Penerbit Angkasa, Bandung. 